\title{
Ivermectin as a potential drug for treatment of COVID-19: an in-sync review with clinical and computational attributes
}

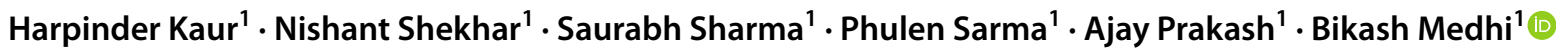

Received: 29 September 2020 / Revised: 9 November 2020 / Accepted: 12 November 2020 / Published online: 3 January 2021

(c) Maj Institute of Pharmacology Polish Academy of Sciences 2021

\begin{abstract}
Introduction COVID-19 cases are on surge; however, there is no efficient treatment or vaccine that can be used for its management. Numerous clinical trials are being reviewed for use of different drugs, biologics, and vaccines in COVID-19. A much empirical approach will be to repurpose existing drugs for which pharmacokinetic and safety data are available, because this will facilitate the process of drug development. The article discusses the evidence available for the use of Ivermectin, an anti-parasitic drug with antiviral properties, in COVID-19.

Methods A rational review of the drugs was carried out utilizing their clinically significant attributes. A more thorough understanding was met by virtual embodiment of the drug structure and realizable viral targets using artificial intelligence (AI)-based and molecular dynamics (MD)-simulation-based study.

Conclusion Certain studies have highlighted the significance of ivermectin in COVID-19; however, it requires evidences from more Randomised Controlled Trials (RCTs) and dose- response studies to support its use. In silico-based analysis of ivermectin's molecular interaction specificity using AI and classical mechanics simulation-based methods indicates positive interaction of ivermectin with viral protein targets, which is leading for SARS-CoV 2 N-protein NTD (nucleocapsid protein $\mathrm{N}$-terminal domain).
\end{abstract}

Keywords Ivermectin · COVID-19 - SARS-CoV-2 $\cdot$ Treatment

\begin{abstract}
Abbreviations
SARS-CoV-2 Severe acute respiratory syndrome coronavirus 2

COVID-19 Coronavirus disease 2019
\end{abstract}

\section{Introduction}

Numerous clinical trials are being reviewed for use of multiple drugs, biologics, and vaccines in COVID-19. Ivermectin is one of the potential drugs that can be repurposed for use against SARS-CoV-2 infection. As of 16-10-2020, 38 Ivermectin trials are registered with ClinicalTrials.gov and 8 with Clinical Trials Registry, India (CTRI) to validate its use in treatment of COVID-19. Table 1 provides details of clinical trials of ivermectin.

Bikash Medhi

drbikashus@yahoo.com

1 Department of Pharmacology, Post Graduate Institute of Medical Education and Reseasrch (PGIMER), Chandigarh 160012, India
Ivermectin belongs to class 'avermectins' consisting of 16-membered macrocyclic lactone compounds [1]. It is approved by FDA for use as an anti-parasitic drug [2] and is known to have nematocidal, insecticidal, and acaracidal properties. Ivermectin was discovered in Japanese Kitasato Institute in the year 1967 and first got approval in 1987 for treatment of onchocerciasis (river blindness) caused by Onchocerca volvulus and transmitted by blackfly in humans. It is efficacious in filarial infections and eradicates parasites of gastrointestinal tract. It is also used for treatment of malaria, trypanosomiasis, head lice, scabies, and leishmaniasis [1]. Moreover, it also exhibits antibacterial and anticancer activities [3]. Ivermectin is safe at higher doses and frequent regimens. Guzzo et al. showed that higher doses of ivermectin $120 \mathrm{mg}$ (up to $2,000 \mu \mathrm{g} / \mathrm{kg}$ ) taken once or at $180 \mathrm{mg}$ (up to $3,000 \mu \mathrm{g} / \mathrm{kg}$ ) taken in split doses over 1 week is well-tolerated and safe [4]. Furthermore, ivermectin has shown antiviral activity against various RNA as well as DNA viruses [5] and is now being evaluated for use in COVID-19. Moreover, it can be used in cases, where use of hydroxychloroquine is not feasible. Hydroxychloroquine in COVID-19 is limited in some cases, because 
Table 1 Clinical trials of ivermectin (from ClinicalTrials.gov and CTRI as of 16-10-2020)

\begin{tabular}{|c|c|c|c|c|c|}
\hline & Trial registration & Phase/status & Intervention/comparator & Study design & Size/location \\
\hline 1 & NCT04343092 & $\begin{array}{l}\text { Phase } 1 \\
\text { Completed }\end{array}$ & Ivermectin & $\begin{array}{l}\text { Randomized, parallel } \\
\text { Masking: double }\end{array}$ & $\begin{array}{l}100 \\
\text { Iraq }\end{array}$ \\
\hline 2 & NCT04422561 & $\begin{array}{l}\text { Phase } 2 / \text { phase } 3 \\
\text { Completed }\end{array}$ & Ivermectin & $\begin{array}{l}\text { Randomized, sequential } \\
\text { Masking: none }\end{array}$ & $\begin{array}{l}340 \\
\text { Egypt }\end{array}$ \\
\hline 3 & NCT04434144 & Completed & $\begin{array}{l}\text { Ivermectin + doxycycline } \\
\text { Hydroxychloroquine + azithro- } \\
\text { mycin }\end{array}$ & Prospective, case-only & $\begin{array}{l}116 \\
\text { Bangladesh }\end{array}$ \\
\hline 4 & NCT04381884 & $\begin{array}{l}\text { Phase } 2 \\
\text { Completed }\end{array}$ & $\begin{array}{l}\text { Ivermectin plus standard care } \\
\text { Control arm will receive stand- } \\
\text { ard care }\end{array}$ & $\begin{array}{l}\text { Randomized, parallel } \\
\text { Masking: none }\end{array}$ & $\begin{array}{l}45 \\
\text { Argentina }\end{array}$ \\
\hline 5 & NCT04446104 & $\begin{array}{l}\text { Phase } 3 \\
\text { Completed }\end{array}$ & $\begin{array}{l}\text { Hydroxychloroquine sulfate } \\
\text { tablets } \\
\text { Ivermectin } 3 \mathrm{Mg} \text { Tab } \\
\text { Zinc } \\
\text { Povidone-iodine } \\
\text { Supplement: vitamin C }\end{array}$ & $\begin{array}{l}\text { Randomized, parallel } \\
\text { Masking: none }\end{array}$ & $\begin{array}{l}4257 \\
\text { Singapore }\end{array}$ \\
\hline 6 & NCT04523831 & $\begin{array}{l}\text { Phase } 3 \\
\text { Completed }\end{array}$ & $\begin{array}{l}\text { Ivermectin and doxycycline } \\
\text { Standard of care }\end{array}$ & $\begin{array}{l}\text { Randomized, parallel } \\
\text { Masking: double }\end{array}$ & $\begin{array}{l}400 \\
\text { Bangladesh }\end{array}$ \\
\hline 7 & NCT04438850 & $\begin{array}{l}\text { Phase } 2 \\
\text { Recruiting }\end{array}$ & $\begin{array}{l}\text { Ivermectin } \\
\text { Placebo }\end{array}$ & $\begin{array}{l}\text { Randomized, sequential } \\
\text { Masking: quadruple }\end{array}$ & $\begin{array}{l}102 \\
\text { Italy }\end{array}$ \\
\hline 8 & NCT04425707 & $\begin{array}{l}\text { Not applicable } \\
\text { Recruiting }\end{array}$ & Ivermectin & $\begin{array}{l}\text { Randomized, parallel } \\
\text { Masking: none }\end{array}$ & $\begin{array}{l}100 \\
\text { Egypt }\end{array}$ \\
\hline 9 & NCT04429711 & $\begin{array}{l}\text { Not applicable } \\
\text { Recruiting }\end{array}$ & Ivermectin oral product & $\begin{array}{l}\text { Randomized, parallel } \\
\text { Masking: quadruple }\end{array}$ & $\begin{array}{l}100 \\
\text { Israel }\end{array}$ \\
\hline 10 & NCT04405843 & $\begin{array}{l}\text { Phase } 2 \text { I Phase } 3 \\
\text { Recruiting }\end{array}$ & $\begin{array}{l}\text { Ivermectin oral product } \\
\text { Placebo }\end{array}$ & $\begin{array}{l}\text { Randomized, parallel } \\
\text { Masking: quadruple }\end{array}$ & $\begin{array}{l}400 \\
\text { Colombia }\end{array}$ \\
\hline 11 & NCT04445311 & $\begin{array}{l}\text { Phase 2IPhase } 3 \\
\text { Recruiting }\end{array}$ & Ivermectin & $\begin{array}{l}\text { Randomized, parallel } \\
\text { Masking: none }\end{array}$ & $\begin{array}{l}100 \\
\text { Egypt }\end{array}$ \\
\hline 12 & NCT04392713 & $\begin{array}{l}\text { Not applicable } \\
\text { Recruiting }\end{array}$ & $\begin{array}{l}\text { Ivermectin } 6 \mathrm{MG} \text { oral tablet (2 } \\
\text { tablets) }\end{array}$ & $\begin{array}{l}\text { Randomized, parallel } \\
\text { Masking: none }\end{array}$ & $\begin{array}{l}100 \\
\text { Pakistan }\end{array}$ \\
\hline 13 & NCT04351347 & $\begin{array}{l}\text { Phase 2IPhase } 3 \\
\text { Recruiting }\end{array}$ & $\begin{array}{l}\text { Ivermectin } \\
\text { Nitazoxanide with ivermectin } \\
\text { Ivermectin wth chloroquine }\end{array}$ & $\begin{array}{l}\text { Randomized, parallel } \\
\text { Masking: none }\end{array}$ & $\begin{array}{l}300 \\
\text { Egypt }\end{array}$ \\
\hline 14 & NCT04431466 & $\begin{array}{l}\text { Phase } 2 \\
\text { Recruiting }\end{array}$ & $\begin{array}{l}\text { Ivermectin } \\
\text { Standard treatment for COVID- } \\
19\end{array}$ & $\begin{array}{l}\text { Randomized, parallel } \\
\text { Masking: triple }\end{array}$ & $\begin{array}{l}64 \\
\text { Brazil }\end{array}$ \\
\hline 15 & NCT04529525 & $\begin{array}{l}\text { Phase 2|Phase } 3 \\
\text { Recruiting }\end{array}$ & $\begin{array}{l}\text { Ivermectin } \\
\text { Placebo }\end{array}$ & $\begin{array}{l}\text { Randomized, parallel } \\
\text { Masking: quadruple }\end{array}$ & $\begin{array}{l}500 \\
\text { Colombia }\end{array}$ \\
\hline 16 & NCT04384458 & $\begin{array}{l}\text { Not applicable } \\
\text { Recruiting }\end{array}$ & $\begin{array}{l}\text { Hydroxychloroquine } \\
\text { Ivermectin }\end{array}$ & $\begin{array}{l}\text { Randomized, parallel } \\
\text { Masking: none }\end{array}$ & $\begin{array}{l}400 \\
\text { Brazil }\end{array}$ \\
\hline 17 & NCT04373824 & $\begin{array}{l}\text { Not applicable } \\
\text { Recruiting }\end{array}$ & Ivermectin & $\begin{array}{l}\text { Non-randomized, crossover } \\
\text { Masking: None }\end{array}$ & $\begin{array}{l}50 \\
\text { India }\end{array}$ \\
\hline 18 & NCT04403555 & $\begin{array}{l}\text { Phase 2IPhase } 3 \\
\text { Recruiting }\end{array}$ & $\begin{array}{l}\text { Ivermectin } \\
\text { Doxycycline } \\
\text { Chloroquine }\end{array}$ & $\begin{array}{l}\text { Randomized, parallel } \\
\text { Masking: None }\end{array}$ & $\begin{array}{l}200 \\
\text { Egypt }\end{array}$ \\
\hline 19 & NCT04447235 & $\begin{array}{l}\text { Phase } 2 \\
\text { Recruiting }\end{array}$ & $\begin{array}{l}\text { Placebo } \\
\text { Ivermectin } \\
\text { Losartan }\end{array}$ & $\begin{array}{l}\text { Randomized, parallel } \\
\text { Masking: double }\end{array}$ & $\begin{array}{l}176 \\
\text { Brazil }\end{array}$ \\
\hline 20 & NCT04472585 & $\begin{array}{l}\text { Phase 1IPhase } 2 \\
\text { Recruiting }\end{array}$ & $\begin{array}{l}\text { Nigella sativa/black cumin } \\
\text { Ivermectin injectable solution } \\
\text { Placebo } \\
\text { Zinc }\end{array}$ & $\begin{array}{l}\text { Randomized, parallel } \\
\text { Masking: quadruple }\end{array}$ & $\begin{array}{l}40 \\
\text { Pakistan }\end{array}$ \\
\hline 21 & NCT04399746 & $\begin{array}{l}\text { Not applicable } \\
\text { Recruiting }\end{array}$ & $\begin{array}{l}\text { Ivermectin } \\
\text { Azithromycin } \\
\text { Cholecalciferol }\end{array}$ & $\begin{array}{l}\text { Non-randomized, parallel } \\
\text { Masking: none }\end{array}$ & $\begin{array}{l}30 \\
\text { Mexico }\end{array}$ \\
\hline
\end{tabular}


Table 1 (continued)

\begin{tabular}{|c|c|c|c|c|c|}
\hline & Trial registration & Phase/status & Intervention/comparator & Study design & Size/location \\
\hline 22 & NCT04374019 & $\begin{array}{l}\text { Phase } 2 \\
\text { Recruiting }\end{array}$ & $\begin{array}{l}\text { Hydroxychloroquine and } \\
\text { azithromycin } \\
\text { Ivermectin } \\
\text { Camostat mesilate } \\
\text { Artemesia annua }\end{array}$ & $\begin{array}{l}\text { Randomized, parallel } \\
\text { Masking: none }\end{array}$ & $\begin{array}{l}240 \\
\text { US }\end{array}$ \\
\hline 23 & NCT04391127 & $\begin{array}{l}\text { Phase } 3 \\
\text { Active, not recruiting }\end{array}$ & $\begin{array}{l}\text { Hydroxychloroquine } \\
\text { Ivermectin } \\
\text { Placebo }\end{array}$ & $\begin{array}{l}\text { Randomized, parallel } \\
\text { Masking: double }\end{array}$ & $\begin{array}{l}108 \\
\text { Mexico }\end{array}$ \\
\hline 24 & NCT04390022 & $\begin{array}{l}\text { Phase } 2 \\
\text { Active, not recruiting }\end{array}$ & $\begin{array}{l}\text { Ivermectin } \\
\text { Placebo }\end{array}$ & $\begin{array}{l}\text { Randomized, parallel } \\
\text { Masking: double }\end{array}$ & $\begin{array}{l}24 \\
\text { Spain }\end{array}$ \\
\hline 25 & NCT04425863 & Active, not recruiting & Ivermectin $5 \mathrm{mg} / \mathrm{mL}$ & Prospective, cohort & $\begin{array}{l}100 \\
\text { Argentina }\end{array}$ \\
\hline 26 & NCT04425850 & Active, not recruiting & $\begin{array}{l}\text { Iota carrageenan } \\
\text { Ivermectin }\end{array}$ & Prospective, cohort & $\begin{array}{l}70 \\
\text { Argentina }\end{array}$ \\
\hline 27 & NCT04407130 & $\begin{array}{l}\text { Phase } 2 \\
\text { Enrolling by invitation }\end{array}$ & $\begin{array}{l}\text { Ivermectin + doxycycline + pla- } \\
\text { cebo } \\
\text { Ivermectin + placebo } \\
\text { Placebo }\end{array}$ & $\begin{array}{l}\text { Randomized, parallel } \\
\text { Masking: double }\end{array}$ & $\begin{array}{l}72 \\
\text { Bangladesh }\end{array}$ \\
\hline 28 & NCT04510233 & $\begin{array}{l}\text { Phase } 2 \\
\text { Not yet recruiting }\end{array}$ & $\begin{array}{l}\text { Ivermectin nasal } \\
\text { Ivermectin oral } \\
\text { Standard care }\end{array}$ & $\begin{array}{l}\text { Randomized, parallel } \\
\text { Masking: none }\end{array}$ & 60 \\
\hline 29 & NCT04360356 & $\begin{array}{l}\text { Phase } 2 \text { I Phase } 3 \\
\text { Not yet recruiting }\end{array}$ & $\begin{array}{l}\text { Ivermectin plus Nitazoxanide } \\
\text { Standard Care }\end{array}$ & $\begin{array}{l}\text { Randomized, parallel } \\
\text { Masking: double }\end{array}$ & 100 \\
\hline 30 & NCT04407507 & $\begin{array}{l}\text { Phase } 2 \\
\text { Not yet recruiting }\end{array}$ & $\begin{array}{l}\text { Ivermectin } \\
\text { Placebo }\end{array}$ & $\begin{array}{l}\text { Randomized, parallel } \\
\text { Masking: single }\end{array}$ & 66 \\
\hline 31 & NCT04392427 & $\begin{array}{l}\text { Phase } 3 \\
\text { Not yet recruiting }\end{array}$ & $\begin{array}{l}\text { Nitazoxanide, ribavirin and } \\
\text { ivermectin for } 7 \text { days }\end{array}$ & $\begin{array}{l}\text { Randomized, sequential } \\
\text { Masking: single }\end{array}$ & $\begin{array}{l}100 \\
\text { Egypt }\end{array}$ \\
\hline 32 & NCT04435587 & $\begin{array}{l}\text { Phase } 4 \\
\text { Not yet recruiting }\end{array}$ & $\begin{array}{l}\text { Ivermectin pill } \\
\text { Combined ART/hydroxychlo- } \\
\text { roquine }\end{array}$ & $\begin{array}{l}\text { Randomized, parallel } \\
\text { Masking: single }\end{array}$ & $\begin{array}{l}80 \\
\text { Thailand }\end{array}$ \\
\hline 33 & NCT04382846 & $\begin{array}{l}\text { Phase } 3 \\
\text { Not yet recruiting }\end{array}$ & $\begin{array}{l}\text { Nitazoxanide } \\
\text { Ivermectin } \\
\text { Chloroquine } \\
\text { Azithromycin }\end{array}$ & $\begin{array}{l}\text { Randomized, parallel } \\
\text { Masking: none }\end{array}$ & 80 \\
\hline 34 & NCT04460547 & Not yet recruiting & $\begin{array}{l}\text { Convalescent plasma transfu- } \\
\text { sion } \\
\text { Hydroxychloroquine } \\
\text { DAS181 } \\
\text { Ivermectin } \\
\text { Interferon beta-1A }\end{array}$ & Retrospective, cohort & 200 \\
\hline 35 & NCT04482686 & $\begin{array}{l}\text { Phase } 2 \\
\text { Not yet recruiting }\end{array}$ & $\begin{array}{l}\text { Ivermectin } \\
\text { Doxycycline Hcl } \\
\text { Zinc } \\
\text { Vitamin D3 } \\
\text { Vitamin C }\end{array}$ & $\begin{array}{l}\text { Randomized, parallel } \\
\text { Masking: triple }\end{array}$ & $\begin{array}{l}300 \\
\text { US }\end{array}$ \\
\hline 36 & NCT04551755 & $\begin{array}{l}\text { Phase } 2 \\
\text { Not yet recruiting }\end{array}$ & $\begin{array}{l}\text { Ivermectin and doxycycline } \\
\text { Placebo }\end{array}$ & $\begin{array}{l}\text { Randomized, parallel } \\
\text { Masking: triple }\end{array}$ & 188 \\
\hline 37 & NCT04530474 & $\begin{array}{l}\text { Phase } 3 \\
\text { Not yet recruiting }\end{array}$ & $\begin{array}{l}\text { Ivermectin pill } \\
\text { Placebo }\end{array}$ & $\begin{array}{l}\text { Randomized, parallel } \\
\text { Masking: triple }\end{array}$ & $\begin{array}{l}200 \\
\text { US }\end{array}$ \\
\hline 38 & NCT04527211 & $\begin{array}{l}\text { Phase } 3 \\
\text { Not yet recruiting }\end{array}$ & Ivermectin & $\begin{array}{l}\text { Randomized, parallel } \\
\text { Masking: quadruple }\end{array}$ & $\begin{array}{l}550 \\
\text { Argentina }\end{array}$ \\
\hline 39 & CTRI/2020/04/024858 & Not yet recruiting & $\begin{array}{l}\text { Ivermectin }(200-400 \mathrm{mcg} / \mathrm{kg} \\
\text { on day } 1 \text { and } 2 \text { in addition to } \\
\text { standard treatment }) \\
\text { Standard treatment }\end{array}$ & $\begin{array}{l}\text { Non-randomized, active con- } \\
\text { trolled }\end{array}$ & $\begin{array}{l}50 \\
\text { New Delhi, India }\end{array}$ \\
\hline
\end{tabular}


Table 1 (continued)

\begin{tabular}{|c|c|c|c|c|c|}
\hline & Trial registration & Phase/status & Intervention/comparator & Study design & Size/location \\
\hline 40 & CTRI/2020/04/024948 & $\begin{array}{l}\text { Phase } 2 \\
\text { Not yet recruiting }\end{array}$ & $\begin{array}{l}\text { Ciclesonide ( } 200 \text { mcg twice a } \\
\text { day for } 7 \text { days) } \\
\text { Hydroxychloroquine }(400 \mathrm{mg} \\
\text { twice a day, Day } 1 \text { followed } \\
\text { by } 200 \mathrm{mg} \text { twice a day on } \\
\text { Days } 2-7) \\
\text { Ivermectin ( } 12 \mathrm{mg} \text { once a day } \\
\text { for } 7 \text { days) } \\
\text { Standard of care }\end{array}$ & Randomized, parallel & $\begin{array}{l}120 \\
\text { New Delhi, India }\end{array}$ \\
\hline 41 & CTRI/2020/05/025224 & $\begin{array}{l}\text { Phase } 2 \\
\text { Not yet recruiting }\end{array}$ & $\begin{array}{l}\text { Ivermectin ( } 12 \mathrm{mg} \text { once a day } \\
\text { at night, oral for } 2 \text { days with } \\
\text { standard of care) } \\
\text { Standard of care }\end{array}$ & Randomized, parallel & $\begin{array}{l}50 \\
\text { Madhya Pradesh, India }\end{array}$ \\
\hline 42 & CTRI/2020/06/025960 & Not yet recruiting & $\begin{array}{l}\text { Ivermectin ( } 12 \mathrm{mg} \text {, per orally, } \\
\text { once a day for } 3 \text { days) } \\
\text { Standard of care }\end{array}$ & $\begin{array}{l}\text { Randomized, parallel, active } \\
\text { controlled }\end{array}$ & $\begin{array}{l}100 \\
\text { Maharashtra, India }\end{array}$ \\
\hline 43 & CTRI/2020/06/026232 & $\begin{array}{l}\text { Phase } 3 \\
\text { Not yet recruiting }\end{array}$ & $\begin{array}{l}\text { Ivermectin (single oral dose of } \\
200 \mathrm{mcg} / \mathrm{kg} \text { ) }\end{array}$ & Single arm & $\begin{array}{l}50 \\
\text { Andhra Pradesh, India }\end{array}$ \\
\hline 44 & CTRI/2020/08/027225 & Not yet recruiting & $\begin{array}{l}\text { Ivermectin (12 mg orally on } \\
\text { days } 1 \text { and } 2) \\
\text { Placebo tablets }\end{array}$ & $\begin{array}{l}\text { Randomized, parallel, placebo } \\
\text { controlled }\end{array}$ & $\begin{array}{l}90 \\
\text { Bihar, India }\end{array}$ \\
\hline 45 & CTRI/2020/08/027282 & $\begin{array}{l}\text { Phase } 3 \\
\text { Not yet recruiting }\end{array}$ & $\begin{array}{l}\text { Ivermectin } 12 \mathrm{mg} \text { or } 36 \mathrm{mg} \text { one } \\
\text { dose orally one time a day } \\
\text { (two intervention arms) } \\
\text { Two multivitamin tablets }\end{array}$ & $\begin{array}{l}\text { Randomized, parallel, multiple } \\
\text { arm }\end{array}$ & $\begin{array}{l}180 \\
\text { Uttar Pradesh, India }\end{array}$ \\
\hline 46 & CTRI/2020/09/027944 & $\begin{array}{l}\text { Phase } 3 \\
\text { Not yet recruiting }\end{array}$ & $\begin{array}{l}\text { Cefixime } 200 \mathrm{mg} \text { (BD, } 5 \text { days), } \\
\text { Ivermectin } 12 \mathrm{mg}(\mathrm{OD} \text {, day } \\
\text { 1), Montelukast } 10 \mathrm{mg}(\mathrm{OD} \text {, } \\
5 \text { days), Ascoril LS } 5 \mathrm{ml} \\
\text { (TID, } 5 \text { days) } \\
\text { Cefixime } 200 \mathrm{mg} \text {, vitamin C, } \\
\text { MVBC, antacids }\end{array}$ & $\begin{array}{l}\text { Randomized, parallel group, } \\
\text { active controlled }\end{array}$ & $\begin{array}{l}30 \\
\text { Maharashtra, India }\end{array}$ \\
\hline
\end{tabular}

it can occasionally cause QTc prolongation and effective antiviral tissue levels need 5-10 days to accrue at maximum safe daily dosage [6]. Ivermectin is not found to be associated with such side effects and treatment with it can also be more cost-effective [7]. Following is an in tuned study about the clinical and molecular attributes of ivermectin.

\section{Mechanism of action of ivermectin}

Ivermectin enhances the activity of GABA receptors or glutamate-gated chloride ion channels in parasites and helminths which blocks the signal between neuron and muscle. GABA sensitive neurons of mammals are protected by blood brain barrier (BBB), and thus protect vertebrates from possible adverse effects of ivermectin. However, invertebrates are dose-dependently susceptible because of extensive distribution of chloride ion channels, where ivermectin generates $\mathrm{Cl}^{-}$influx, resulting in hyperpolarization which impedes myosin II light chain's phosphorylation. This promotes paralysis of somatic muscles with concomitant uncoordinated movement, starvation because pharyngeal pumping is inhibited, and death. Ivermectin's affinity for parasite is 100 times more than for brain of mammals [1]. Immunomodulation of host response is another mechanism by which ivermectin can act achieved by activation of neutrophils, increased C-reactive protein and interleukin-6 levels [8]. For its antiviral activity, ivermectin is believed to act through inhibition of nuclear import of proteins of virus as well as of host. Majority of the RNA virus depend on IMP $\alpha / \beta 1$ at the time of infection, and ivermectin inhibits this import and enhances the antiviral response [9]. Another mechanism of action by which ivermectin is believed to act involves transmembrane receptor CD147. CD147 along with ACE-2 has been recognized as a key binding site for SARS-CoV-2 spike protein. The potential for major dose-response gains is assessed on the basis of studies that indicate that ivermectin shields SARS-CoV-2 spike protein which binds to CD147 and ACE-2 [6]. Furthermore, Rizzo suggested that ivermectin may have a possible ionophore role. Ionophores have been appreciated for their antibiotic activity 
and their role as antiviral and anticancer agents is also hypothesized [10].

Another, mechanism of action of ivermectin which needs consideration involves the allosteric modulation of the $\mathrm{P} 2 \mathrm{X}_{4}$ receptor. $\mathrm{P} 2 \mathrm{X}$ receptors are the channels selective to cation and are gated by extracellular ATP [11]. They mediate a number of functions in health and disease through extracellular ATP [12, p. 4]. From the seven subunits of $\mathrm{P} 2 \mathrm{X}$ receptors, $\mathrm{P} 2 \mathrm{X}_{4}$ is most sensitive to ivermectin. Priel et al. studied the effect of ivermectin on whole cell as well as single channel currents of $\mathrm{P}_{2} \mathrm{X}_{4}$ receptors of humans expressed in HEK293 cells. Authors observed that at low ivermectin concentrations maximal current activated by ATP is predominantly activated and at high concentrations rate of current deactivation is predominantly slowed and potency of ATP is enhanced. Hence, ivermectin possibly binds to different extracellular sites (higher and lower affinity sites) on the receptor and modulate the amplitude of current and rate of deactivation of current [11]. Positive allosteric modulation of $\mathrm{P} 2 \mathrm{X}_{4}$ by ivermectin enhances ATP-mediated secretion of CXCL5 (pro-inflammatory chemokine). CXCL5 is a chemo-attractant molecule expressed in inflammatory cells in different tissues and modulates neutrophil chemotaxis and chemokine scavenging [13]. Furthermore, ivermectin $(2 \mathrm{mg} / \mathrm{kg}$ ) was shown to have anti-inflammatory effects in animal model of allergic asthma. Immune cell recruitment, cytokine production in broncho-alveolar lavage fluid, $\mathrm{IgE}$ and $\mathrm{IgG} 1$ secretion in serum as well as hyper-secretion of mucus by goblet cells was reduced significantly by ivermectin [14]. Moreover, ivermectin blocked inflammatory cytokine production induced by LPS in mice. Production of IL-6, IL-1ss, and TNF- $\alpha$ was reduced considerably both in vitro and in vivo and LPS induced translocation of NF- $\mathrm{KB}$ was curbed too [15]. Quantitative proteomics study by $\mathrm{Li}$ et al. had revealed broad-spectrum antiviral property of ivermectin which can be of use in treatment of COVID-19 [16].

Figure 1 describes possible mechanism of actions of ivermectin.

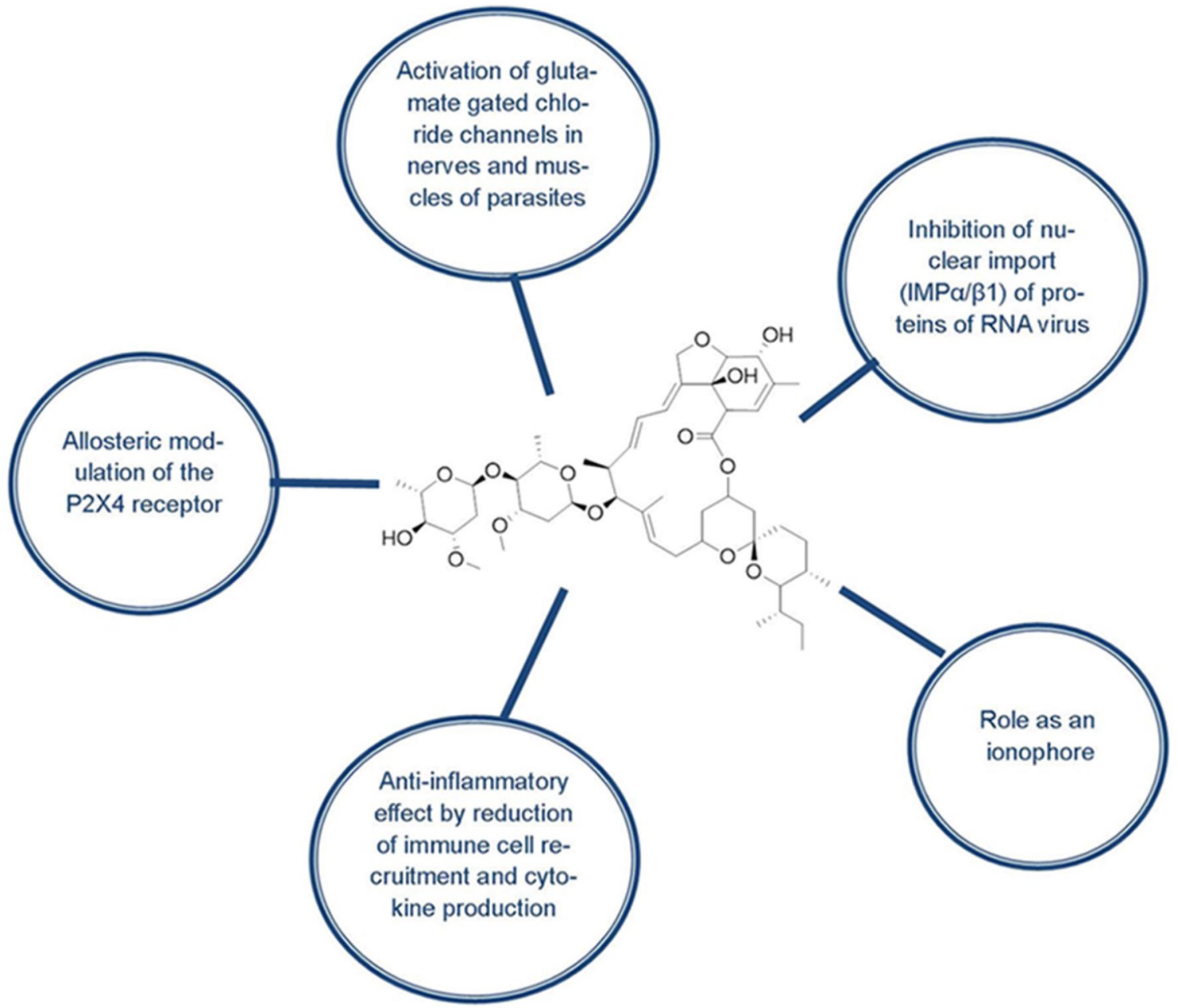

Fig. 1 Mechanism of actions of ivermectin 


\section{Evidence available for use of Ivermectin in COVID-19}

In silico, in vitro as well as clinical studies have been carried out to check the efficacy of ivermectin against SARS-CoV-2 infection and are summarized in the subsequent paragraphs.

\section{In silico}

Abdel-Mottaleb et al. reported that ivermectin, hydroxychloroquine and favipiravir are the strongest binding drugs to ACE-2 as well as S protein [17] and molecular modeling study by Dayer demonstrated that ivermectin is one of the most efficient agent that shields SARS-CoV-2 spike protein from host cell receptors [18]. According to another study by Lehrer et al. ivermectin docked in the region of leucine 91 of the spike and histidine 378 of the ACE2 receptor. Furthermore, a study by Daghir Janabi reported high binding affinity of ivermectin to RNA dependent RNA polymerase (RdRp) [19].

\section{In vitro}

Caly et al. showed that when $5 \mu \mathrm{M}$ of ivermectin was added to Vero/hSLAM cells with SARS-CoV-2 isolate Australia/ VIC01/2020, viral RNA in the supernatant (indicated virions that were released) was reduced by $93 \%$ and RNA of virus associated with cell was reduced by $99.8 \%$ (indicated virions that were not released and packaged). Furthermore, it was stated that by $48 \mathrm{~h}$ ivermectin brought about 5000 fold reduction of viral RNA and the IC50 was found out to be $\sim 2 \mu \mathrm{M}[2]$.

\section{Clinical}

Rajter et al. carried out a retrospective cohort study $(n=280)$ of patients confirmed with SARS-CoV-2 infection hospitalized at a hospital in South Florida. They reviewed 173 patients who received treatment with ivermectin (at least one dose of ivermectin $200 \mathrm{mcg} / \mathrm{kg}$ orally along with usual clinical care) and 107 who received usual care and found out that treatment with ivermectin was related to lower mortality particularly in patients needing higher inspired oxygen or ventilator support. [20]. Another study by Alam et al. reported that ivermectin and doxycycline's combination is very efficacious in SARS-CoV-2 clearance in patients with mild to moderate disease. In their observational/cross-sectional study, they included 100 mild and moderate RT-PCR confirmed COVID-19 patients from Bangladesh. They were treated with combination of ivermectin $(0.2 \mathrm{mg} / \mathrm{kg}$ single dose $)$ and doxycycline (100 $\mathrm{mg}$ daily for 10 days) in addition to supportive treatment. Symptoms of all the patients improved within $72 \mathrm{~h}$, no side effects were observed, intensive care admission was not required, no deaths were reported, and all of them tested negative [21]. Furthermore, Gorial et al. conducted a pilot clinical trial to evaluate the efficacy of ivermectin as additional treatment to hydroxychloroquine and azithromycin in mild to moderate hospitalized COVID-19 patients. 16 patients who were given ivermectin ( $200 \mathrm{mcg} / \mathrm{kg}$ on day of admission) as additional treatment to hydroxychloroquine and azithromycin were compared to control group $(n=71)$ who were given hydroxychloroquine and azithromycin. Cure rate was $100 \%$ in case of ivermectin group and $97.2 \%$ (69 out of 71 patients) in case of control group. Also the mean time to stay in the hospital was considerable less for the ivermectin group. No side effects were seen [22]. In another prospective comparative study by Rahman et al. $(n=400$; patients with mild to moderate disease), effect of ivermectin in combination with doxycycline was compared to hydroxychloroquine in combination with azithromycin. 200 patients were administered ivermectin (18 mg on day 1) and doxycycline (100 mg two times a day for 5 days), whereas the another 200 were administered hydroxychloroquine ( $800 \mathrm{mg}$ on day 1 and after that $400 \mathrm{mg}$ every day for 10 days) and azithromycin (500 mg on day 1 and after that $250 \mathrm{mg}$ every day for 4 days). According to the results ivermectin combined with doxycycline was safe and efficacious in early viral clearance in patients with mild to moderate disease and took less time than hydroxychloroquine and azithromycin combination for viral clearance [23]. Chowdhury et al. also compared combination of ivermectin and doxycycline to hydroxychloroquine and azithromycin in mild to moderate COVID-19 patients. Patients were categorized into 2 groups. The first group $(n=60)$ received ivermectin $(200 \mathrm{mcg} / \mathrm{kg}$ one dose $)$ and doxycycline (100 mg two times a day for 10 days) and the second $(n=56)$ received hydroxychloroquine $(400 \mathrm{mg}$ on day 1 and after that $200 \mathrm{mg}$ two times a day for 9 days) and azithromycin (500 mg every day for 5 days). According to the study, ivermectin and doxycycline were superior to hydroxychloroquine and azithromycin in mild to moderate COVID-19 patients but the variation in time to become symptom free and time to negative PCR was not significant statistically [24]. Furthermore, Wijaya and Salim reported that there was significant clinical and radiological improvement in 3 confirmed COVID-19 patients after one dose of ivermectin [25]. In a cross-sectional study by Malik et al., majority of health care professionals were treated with ivermectin either in combination with azithromycin or with doxycycline and favorable outcomes were observed [26]. 


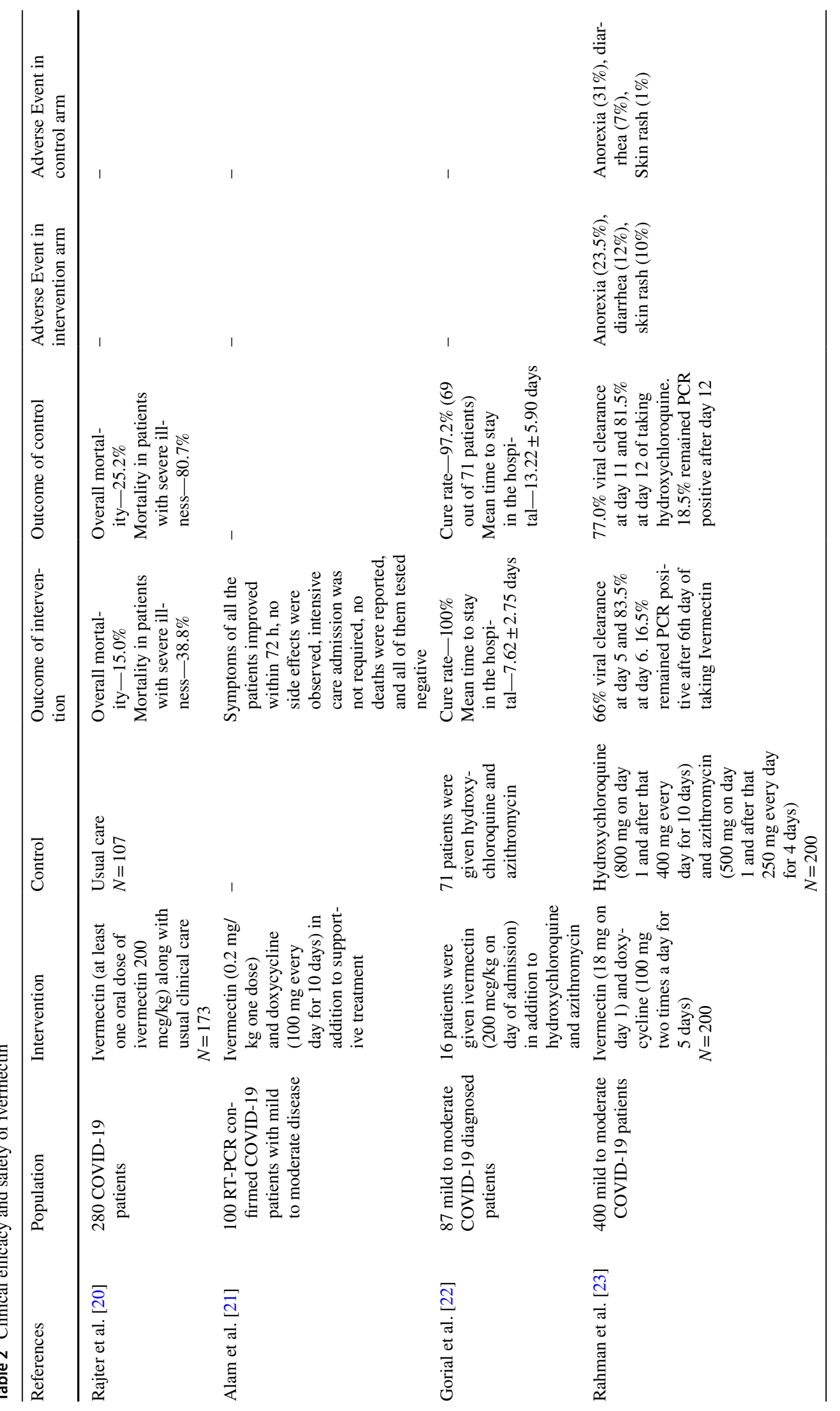




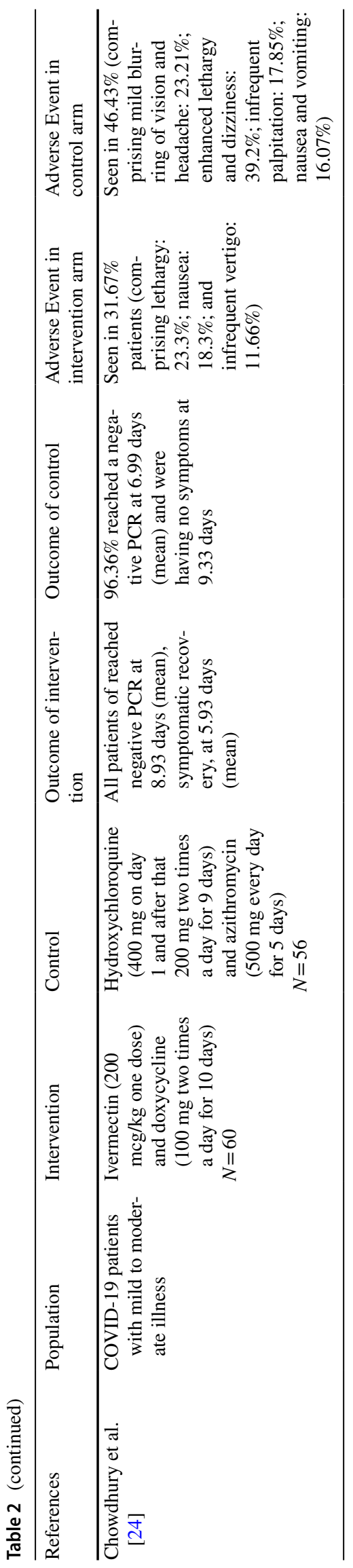

Table 3 Binding score of ivermectin against SARS-CoV-2 proteins

\begin{tabular}{lll}
\hline & Model & $\begin{array}{l}\text { CNN } \\
\text { BindingDB } \\
\text { score }\end{array}$ \\
\hline 1 & 3CL protease & 9.48 \\
2 & RNA dependent RNA polymer- & 9.32 \\
& ase & \\
3 & Helicase & 9.34 \\
4 & Nucleocapsid & 9.41 \\
\hline
\end{tabular}

*Table 2 provides data on clinical efficacy and safety of ivermectin.

\section{Artificial intelligence-based study}

The Drug-Target Interaction (DTI) may be predicted by Artificial Intelligence using Deep Learning methods. This has been done by DeepPurpose, a Deep learning framework for drug discovery [27]. The drugs as well as the protein targets have to be encoded to formats appropriate for model creation. The drug (Ivermectin) and the protein targets were encoded into convolutional neural network (CNN) format [28]. Prediction of DTI was made against a model trained on drug target interactions available in the BindingDB database which consists of 13,349 drugs, 1,658 proteins and 74,641 interactions [29]. The pretrained model was available through the DeepPurpose framework (MSE of 0.600 and Concordance Index of 0.857). Analyzing the interaction of Ivermectin with SARS-CoV-2 proteins through Artificial Intelligence based DTI framework predicted a binding score of 9.48 against 3CL protease, 9.32 against RNA dependentRNA polymerase, 9.34 against Helicase and 9.41 against nucleocapsid protein.

Table 3 provides binding score of ivermectin against SARS-CoV-2 proteins. Model was trained on BindingDB and both drug and protein sequence was encoded in CNN.

\section{Molecular dynamics simulations-based study}

Molecular dynamics simulations can be applied to analyze and conclude a framework of molecular level of microbial pathogenesis, but they are still open for improvements in algorithmic precision and methodologies that can effectively assess the bio-system of topics. In this study the molecular interactions of the ivermectin with some primary SARS-CoV-2 protein targets were simulated, namely with nucleocapsid protein $\mathrm{N}$-terminal domain $(6 \mathrm{M} 3 \mathrm{M})$, spike S1 RBD (PDB: 6M17), spike S2 fusion domain (6VXX), CL protease (6Y2F), nsp7, nsp8, nsp 12 and nsp13 (6XEZ) 
as distinct components of RDRP protein and lastly ORF6 protein (I-tasser model) [30-32]. The proteins were optimized and simulated at physiological conditions $(\mathrm{pH} 7.4$, Temp $=310 \mathrm{~K}$, Press $=1.01325 \mathrm{Bar}$ ). All the simulations were performed on Desmond on Dell Precision tower 3630 with Quadro RTX 4000 GPU computing [33].

The idea that can be obtained from the molecular interaction profile of ivermectin with selected viral proteins is that the ivermectin shows a distinction between the degree of interaction specificity among the various viral targets, but still exhibits comparable binding profile with some. The $\mathrm{C} \alpha$ RMSD for the $100 \mathrm{~ns}$ MD simulation shows the variation in average conformation change influenced by ivermectin on the target proteins (Fig. 2). The extremely smaller protein structures (nsp7, ORF6) encountered higher deviations in overall conformation and opposite implies for the bigger protein ( $\mathrm{S} 2$ fusion domain). The residue interaction index and trajectory visualization add more to the information about the nature of interaction. It can be deduced that Ivermectin has efficient binding with: (1) spike S1-RBD, where it binds with Thr 500, Asn 501 and Tyr 505 residues (Fig. 3b). These sites are critical to the SARS CoV-2 spike proteinmediated recognition from ACE-2 receptors in the host cellular system. Prominent H-bonding with Thr 500 and Asn 501 and water bridges were observed for more than $80 \%$ of simulation (Fig. 4a). (2) Spike S2-fusion domain, it binds to two specific regions of S2 fusion domain namely HR-1 sub-domain and fusion peptide domain. Major interactions were observed at the HR-1 domain, where it binds for up to $80 \%$ of simulation duration with Ser 968, Asn 969 and Gly 971 with H-bonds and water bridges. The fusion peptide region also exhibits weak affinity for ivermectin at Phe 797 and extremely weak interactions at Pro 792 residues with hydrophobic contact (Figs. 3c, 4b). The S2 fusion domain is necessary to build the fusion bridge between the viral and host membrane, where the fusion peptide is highly non-polar flexible region which facilitates the direct contact with the host membrane components. (3) N-protein, the poly-nucleotide (RNA) interacting cleft of nucleocapsid N-protein characterized by residues Arg 69, Tyr 124, Asn 127 and Glu 137 were found interacting with ivermectin with rich H-bond ratio, see Figs. 3a and 4c. (4) Main protease, the main protease of the SARS-CoV 2 is another target which exhibits good affinity for ivermectin in inhibition site too at Glu 19, Thr 25, Glu 47, Leu 50 (Figs. 3d, 4d). The spatial localization of ivermectin molecule on the protein surface is illustrated with the active residue characterization in Fig. 5. On the contrary, RDRP components (nsp7, nsp8, nsp12) with helicase (nsp13) and the ORF-6 fragment had weak specificity for ivermectin and could be characterized as weak targets for ivermectin as there was significantly low number of observed drug-protein collisions in simulation.

The broad specificity of the ivermectin to these proteins and other reported pharmacological targets can be attributed

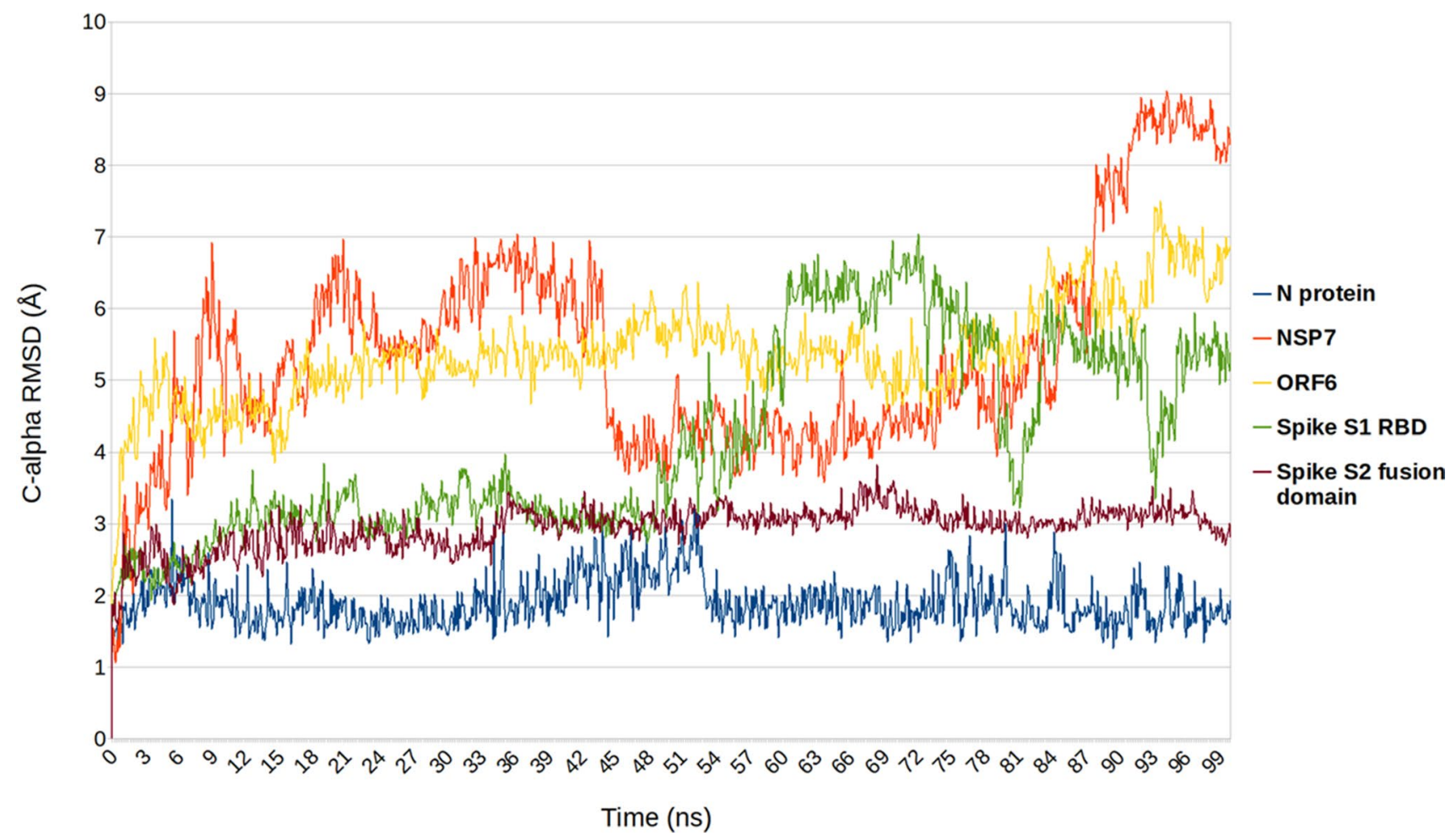

Fig. 2 C-alpha RMSD of different SARS-CoV-2 protein targets representing contact with Ivermectin in 100 ns simulation 
A
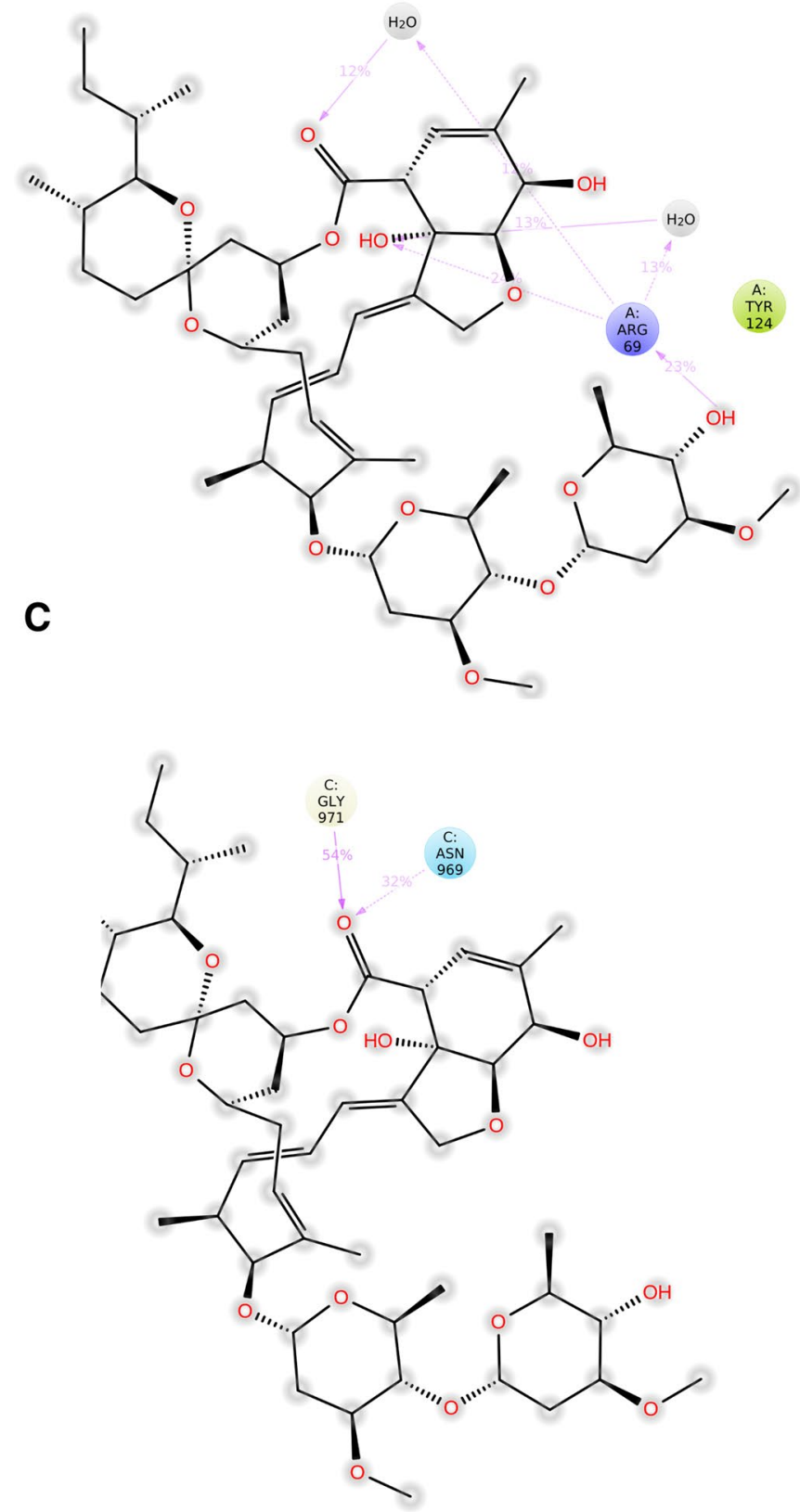

Fig. $32 \mathrm{D}$ contact with the protein targets of ivermectin with the interaction strength represented with adjacent active site residues (magenta continuous line: $\mathrm{H}-$ bond with $\mathrm{C} \alpha$ of protein; magenta dotted line: H-bond with side chain groups; green residue: hydrophobic;

to its exposed hydroxyl and ester groups that can highly assist as $\mathrm{H}-$ bond donor.
B

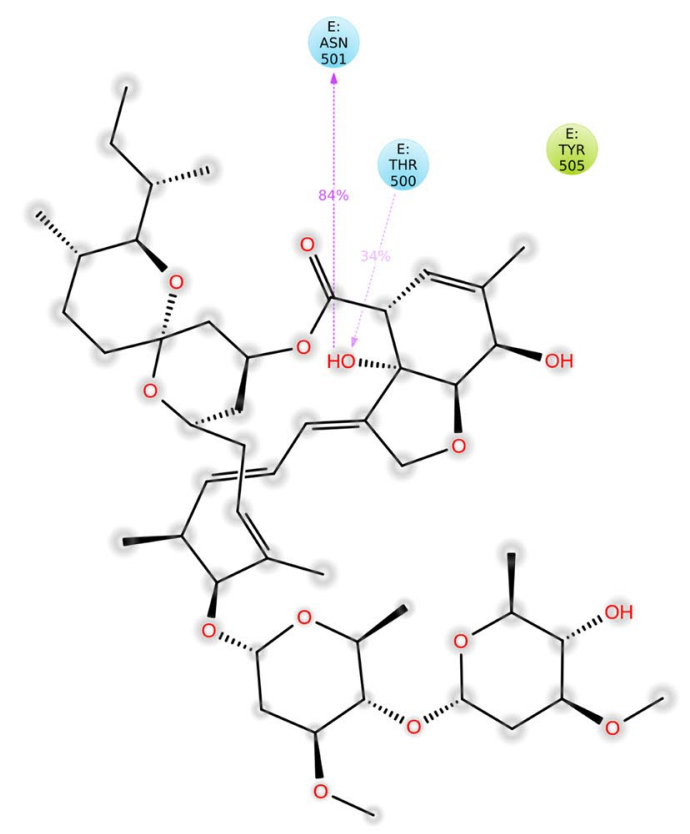

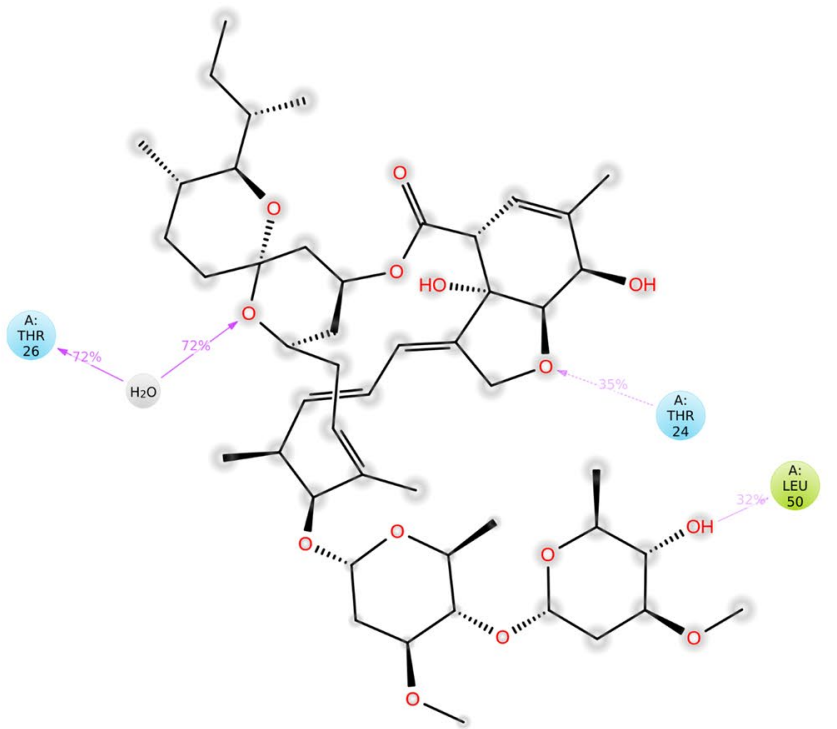

blue residue: polar residue, grey dots: solvent exposure) a $\mathrm{N}$-protein contact with Ivermectin, b S1-RBD contact with Ivermectin, c S2 fusion peptide contact with Ivermectin, d CL protease contact with Ivermectin

\section{Discussion}

From the evidence that is available and our artificial intelligence and molecular dynamics simulations based studies, ivermectin can be thought of as a potential drug for the treatment of COVID-19. Beneficial results have been observed with ivermectin in clinical studies. However, great diligence 

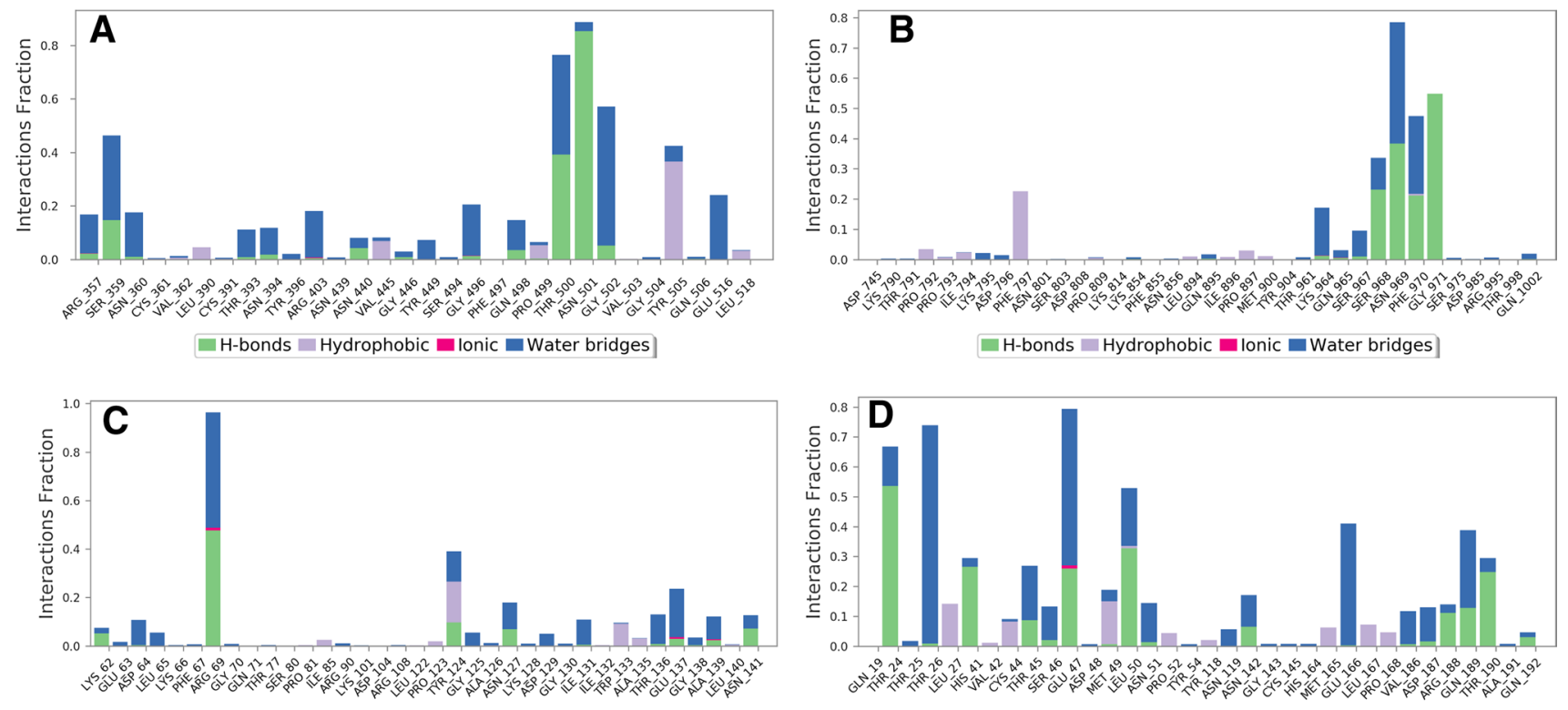

H-bonds $\quad$ Hydrophobic $\square$ lonic $\square$ Water bridges

H-bonds Hydrophobic $\square$ lonic Water bridges

Fig. 4 Ivermectin contact profile with SARS CoV-2 proteins a S1-RBD, b S2 fusion domain, $\mathbf{c}$ N protein NTD and d CL protease

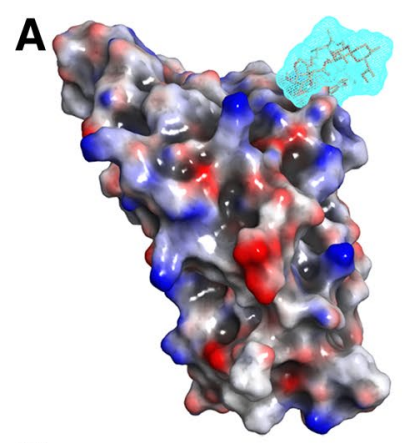

C
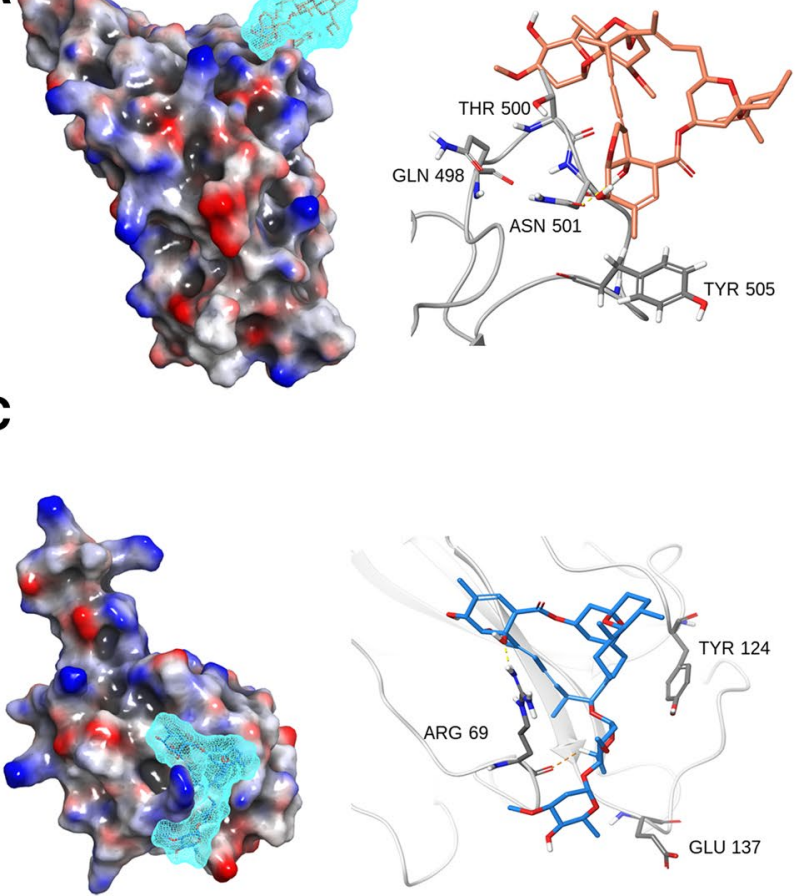

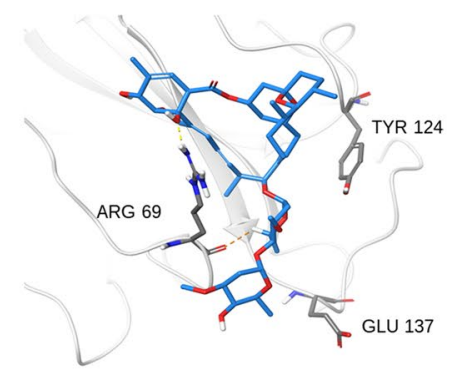

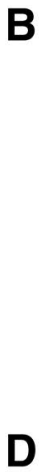
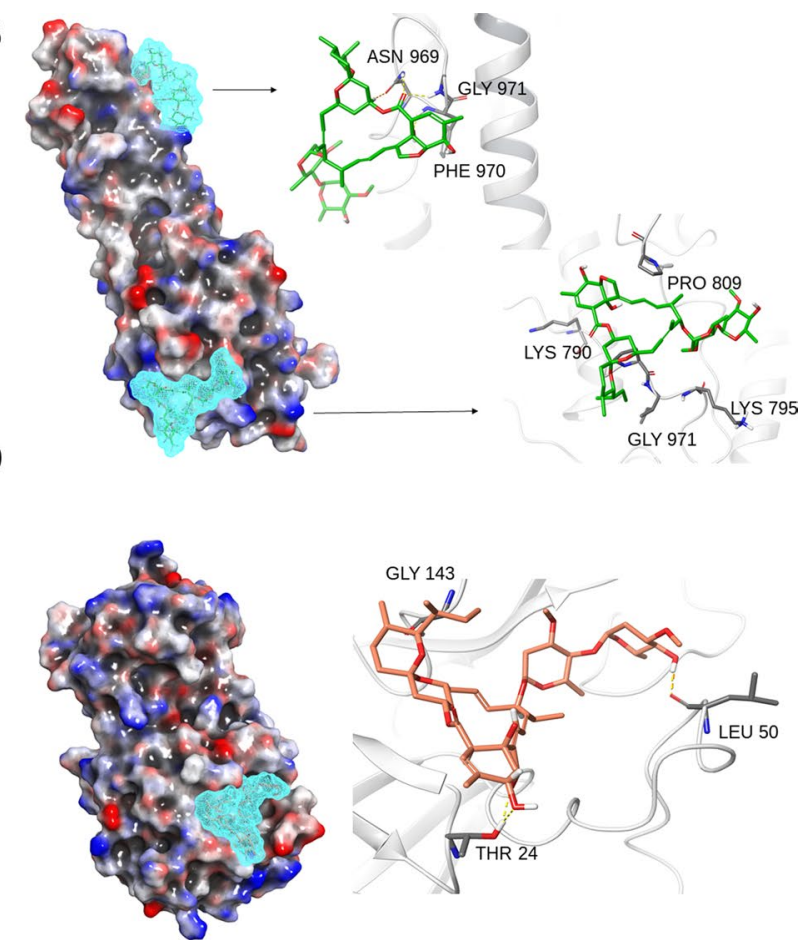

Fig. 5 The 3D representation of ivermectin showing interaction points of ivermectin molecule in final bound trajectory frames with: a S1-RBD, b S2 fusion domain, $\mathbf{c}$ N protein NTD and $\mathbf{d}$ main protease (Yellow dotted line: H-bond, orange dotted line: indistinct weak interaction)

and regulatory review is required for testing of ivermectin in severe COVID-19 because of various reasons. As ivermectin targets the invertebrate's glutamate gated chloride channels, it can also cross-target mammalian GABA-gated chloride channels in the CNS. In normal conditions, this is prevented by BBB; however, in individuals having hyperinflammatory state, endothelial permeability at BBB may be enhanced, leading to drug leakage into the CNS and 
neurotoxicity. Furthermore, anti-retroviral drugs used against SARS-CoV-2 like lopinavir/ritonavir and darunavir/ cobicstat potently inhibit cytochrome P450 3A4 (ivermectin's main metabolic pathway) and if used concurrently with ivermectin can increase the systemic exposure to ivermectin. Ritonavir and cobicistat also inhibits P-glycoprotein efflux pump in BBB [34]. Moreover, well-controlled dose response study needs to be considered for carrying out a clinical trial of ivermectin. Schmith et al. carried out simulations with the help of available population pharmacokinetic model for predicting total and unbound plasma concentration-time profiles of ivermectin $(200 \mu \mathrm{g} / \mathrm{kg}, 60 \mathrm{mg}$, and $120 \mathrm{mg})$ after administration of single and repeat fasted dose. According to their results, the IC50 value of ivermectin as reported by Caly et al. was much higher than the maximum plasma concentration achieved after administration of the above mentioned three doses of ivermectin when administered fasted. Hence, the chances of success of a trial that use the approved ivermectin dose $(200 \mu \mathrm{g} / \mathrm{kg})$ are less. They further suggested evaluation of use of combined therapy in vitro and ivermectin's inhaled treatment if feasible [35]. Furthermore, Momekove et al. also reported that according to pharmacokinetic data that is available from clinically relevant and excessive dosing studies SARS-CoV 2 in vitro inhibitory concentrations $(5 \mu \mathrm{M} / \mathrm{L})$ are not probable to be achievable in humans [36]. Next, ivermectin's cellular uptake by endothelial cells is limited, because it is highly bound (93\%) to plasma proteins. Furthermore, ivermectin's total lung concentration reached only $100 \mathrm{ng} / \mathrm{g}$ (around $0.1 \mu \mathrm{M}$ ) in lung tissue in calves injected with $200 \mu \mathrm{g} / \mathrm{kg}$, suggesting that accumulation of ivermectin would not be enough to accomplish the antiviral effect with conventional doses [37]. Jermain et al. developed a minimal physiologically-based pharmacokinetic model to simulate ivermectin's exposure to human lungs post oral doses $(12,30$, and $120 \mathrm{mg}$ ). The simulated exposure of ivermectin to lungs achieved a concentration of $772 \mathrm{ng} / \mathrm{mL}$, lower than the reported IC50 for ivermectin in vitro $(1750 \mathrm{ng} / \mathrm{mL})$ [38].

In molecular dynamics simulation studies, the interaction of ivermectin with multiple (four) viral targets with relatable specificity and nature of interaction suggest, i.e., which majorly involves rich H-bonds, can show inhibitory actions resembling the estimated outcomes from the MD simulations prototyped in physiological conditions. The binding coordinates of ivermectin observed were at the prime regions crucial for the activity of particular SARS$\mathrm{CoV}$ proteins. The least structural deviation with the nucleocapsid protein $\mathrm{N}$ terminal domain $(1.89 \AA \pm 0.33)$ and high interaction ratio points toward the suggestion that ivermectin exhibits relatively high affinity for $\mathrm{N}$ protein. The nucleocapsid shuttling has been proposed to be facilitated via human Importin $\alpha / \beta$ into the nuclear matrix $[39,40]$. The reported binding of ivermectin to importin $\alpha / \beta$ and notably low infection in ivermectin treated patients, might also possibly suggest that there is noticeable binding with the nucleocapsid cargo itself.

\section{Conclusion}

Hence, keeping in view the available evidence from clinical studies ivermectin can be a potential drug as it reduced mortality and improved symptoms of patients with COVID19. Moreover, ivermectin in combination with doxycycline seems effective. However, more RCTs and dose response studies are required to justify its use. The molecular specificity of ivermectin seems to be quite assorted as there can be seen good binding profiles with spike S1 and S2 domains in addition to CL protease inhibition site. The marginally efficient binding to the Nucleocapsid (N) protein might point towards the idea that nucleocapsid activity gets affected after its trans-nuclear import. Hence, ivermectin might be involved in the inhibition of $\mathrm{N}$ protein (has a role in nuclear import) and as the exact mechanism is not known, we are describing the best possible target estimation for ivermectin. The findings incline the possibility of ivermectin to be a multi-targeted drug (host and virus-targeted) especially in the case of COVID-19.

\section{Future recommendations}

Ivermectin has been reported to show potent efficacy as an antiviral; however, its application is limited because of pharmacokinetic difficulties such as low solubility. These difficulties can be overcome by formulating liposomal ivermectin or other ivermectin formulations with improved properties. Furthermore, inhalation therapy of ivermectin can deliver high drug concentration to the lungs and airways to reduce the viral loads in such areas [41] or else it can be used in combination with other agents that differ in mechanism of action [38].

\section{References}

1. Juarez M, Schcolnik-Cabrera A, Dueñas-Gonzalez A. The multitargeted drug ivermectin: from an antiparasitic agent to a repositioned cancer drug. Am J Cancer Res. 2018;8(2):317-31.

2. Caly L, Druce JD, Catton MG, Jans DA, Wagstaff KM. The FDA-approved drug ivermectin inhibits the replication of SARSCoV-2 in vitro. Antiviral Res. 2020. https://doi.org/10.1016/j. antiviral.2020.104787.

3. Sharun $\mathrm{K}$, et al. Ivermectin, a new candidate therapeutic against SARS-CoV-2/COVID-19. Ann Clin Microbiol Antimicrob. 2020. https://doi.org/10.1186/s12941-020-00368-w.

4. Guzzo CA, et al. Safety, tolerability, and pharmacokinetics of escalating high doses of ivermectin in healthy adult 
subjects. J Clin Pharmacol. 2002;42(10):1122-33. https://doi. org/10.1177/009127002401382731.

5. Heidary F, Gharebaghi R. Ivermectin: a systematic review from antiviral effects to COVID-19 complementary regimen. J Antibiot (Tokyo). 2020. https://doi.org/10.1038/s41429-020-0336-z.

6. Scheim D. Ivermectin for COVID-19 treatment: clinical response at quasi-threshold doses via hypothesized alleviation of CD147-mediated vascular occlusion. Social Science Research Network, Rochester, NY, SSRN Scholarly Paper ID 3636557. 2020. https://papers.ssrn.com/abstract $=3636557$. Accessed 12 Aug 2020.

7. Gupta D, Sahoo AK, Singh A. Ivermectin: potential candidate for the treatment of Covid 19. Braz J Infect Dis Off Publ Braz Soc Infect Dis. 2020. https://doi.org/10.1016/j.bjid.2020.06.002.

8. Njoo FL, Hack CE, Oosting J, Luyendijk L, Stilma JS, Kijlstra A. C-reactive protein and interleukin-6 are elevated in onchocerciasis patients after ivermectin treatment. J Infect Dis. 1994;170(3):6638. https://doi.org/10.1093/infdis/170.3.663.

9. Choudhary R, Sharma AK, Choudhary R. Potential use of hydroxychloroquine, ivermectin and azithromycin drugs in fighting COVID-19: trends, scope and relevance. New Microbes New Infect. 2020. https://doi.org/10.1016/j.nmni.2020.100684.

10. Rizzo E. Ivermectin, antiviral properties and COVID-19: a possible new mechanism of action. Naunyn Schmiedebergs Arch Pharmacol. 2020;393(7):1153-6. https://doi.org/10.1007/s0021 0-020-01902-5.

11. Priel A, Silberberg SD. Mechanism of ivermectin facilitation of human P2X4 receptor channels. J Gen Physiol. 2004. https:// pubmed.ncbi.nlm.nih.gov/14769846/. Accessed 14 Oct 2020.

12. Stokes L, Layhadi JA, Bibic L, Dhuna K, Fountain SJ. P2X4 receptor function in the nervous system and current breakthroughs in pharmacology. Front Pharmacol. 2017;8:291. https://doi. org/10.3389/fphar.2017.00291.

13. Layhadi JA, Turner J, Crossman D, Fountain SJ. ATP evokes $\mathrm{Ca} 2+$ responses and CXCL5 secretion via $\mathrm{P} 2 \mathrm{X} 4$ receptor activation in human monocyte-derived macrophages. J Immunol Baltim Md 1950. 2018;200(3):1159. https://doi.org/10.4049/jimmu nol.1700965.

14. Yan S, et al. Anti-inflammatory effects of ivermectin in mouse model of allergic asthma. Inflamm Res Off J Eur Histamine Res Soc Al. 2011;60(6):589-96. https://doi.org/10.1007/s0001 1-011-0307-8.

15. Zhang $X$, et al. Ivermectin inhibits LPS-induced production of inflammatory cytokines and improves LPS-induced survival in mice. Inflamm Res Off J Eur Histamine Res Soc. 2008a;57(11):524-9. https://doi.org/10.1007/s00011-008-8007-8.

16. Li N, Zhao L, Zhan X. Quantitative proteomics reveals a broadspectrum antiviral property of ivermectin, benefiting for COVID19 treatment. J Cell Physiol. 2020. https://doi.org/10.1002/ jcp.30055.

17. Abdel-Mottaleb MS, Abdel-Mottaleb Y. In search for effective and safe drugs against SARS-CoV-2 part I: simulated interactions between selected nutraceuticals, ACE2 enzyme and S protein simple peptide sequences. ChemRxiv. 2020. https://doi.org/10.26434 /chemrxiv.12155235.v1.

18. Dayer MR. Coronavirus (2019-nCoV) deactivation via spike glycoprotein shielding by old drugs. Bioinform Study. 2020. https:// doi.org/10.20944/preprints202005.0020.v1.

19. AH Daghir Janabi. Effective anti-SARS-CoV-2 RNA dependent RNA polymerase drugs based on docking methods: the case of milbemycin, ivermectin, and baloxavir marboxil. Avicenna J Med Biotechnol. 2020;12(4):246-50.

20. Rajter JC, Sherman M, Fatteh N, Vogel F, Sacks J, Rajter J-J. ICON (ivermectin in COvid nineteen) study: use of ivermectin is associated with lower mortality in hospitalized patients with COVID19. medRxiv. 2020. https://doi.org/10.1101/2020.06.06.20124461.
21. Alam MT, Murshed R, Bhiuyan E, Saber S, Alam RF, Robin RC. A case series of 100 COVID-19 positive patients treated with combination of ivermectin and doxycycline. J Bangladesh Coll Physicians Surg. 2020. https://doi.org/10.3329/jbcps.v38i0.47512.

22. Gorial FI, et al. Effectiveness of ivermectin as add-on therapy in COVID-19 management Pilot trial. medRxiv. 2020. https://doi. org/10.1101/2020.07.07.20145979.

23. Rahman MA, Iqbal SA, Islam MA, Niaz MK, Hussain T, Siddiquee TH. Comparison of viral clearance between ivermectin with doxycycline and hydroxychloroquine with azithromycin in COVID-19 patients. J Bangladesh Coll Physicians Surg. 2020. https://doi.org/10.3329/jbcps.v38i0.47514.

24. A comparative observational study on ivermectin-doxycycline and hydroxychloroquine-azithromycin therapy on COVID19 patients. ResearchGate. https://www.researchgate.net/publicatio n/342159343_A_comparative_observational_study_on_Iverm ectin-_Doxycycline_and_Hydroxychloroquine-Azithromycin_ therapy_on_COVID19_patients. Accessed 09 Aug 2020.

25. Wijaya NS, Salim S. Ivermectin as a potential therapeutic agent for COVID-19-case studies. Cermin Dunia Kedokt. 2020;47(7):370-2.

26. Malik F-T-N, et al. Clinical presentation, management and inhospital outcome of healthcare personnel with COVID-19 disease. Cureus. 2020;12(8):e10004. https://doi.org/10.7759/cureus.10004

27. Huang K, Fu T, Xiao C, Glass L, Sun J. Deep purpose: a deep learning based drug repurposing toolkit. ArXiv Prepr. ArXiv200408919. 2020.

28. Krizhevsky A, Sutskever I, Hinton GE. Imagenet classification with deep convolutional neural networks. In: Advances in neural information processing systems. 2012. p. 1097-1105.

29. Liu T, Lin Y, Wen X, Jorissen RN, Gilson MK. BindingDB: a webaccessible database of experimentally determined protein-ligand binding affinities. Nucleic Acids Res. 2007;35(Suppl_1):198-201.

30. Zhang Y. I-TASSER server for protein 3D structure prediction. BMC Bioinform. 2008b;9(1):40.

31. Sarma $P$, et al. In-silico homology assisted identification of inhibitor of RNA binding against 2019-nCoV N-protein N terminal domain. J Biomol Struct Dyn. 2020. https://doi.org/10.1080/07391 102.2020.1753580.

32. Prajapat $\mathbf{M}$, et al. Virtual screening and molecular dynamics study of approved drugs as inhibitors of spike protein S1 domain and ACE2 interaction in SARS-CoV-2. J Mol Graph Model. 2020;101:107716.

33. Chow E et al. Desmond performance on a cluster of multicore processors. DE Shaw Research Technical Report DESRES. TR-2008-01. http://deshawresearch.com. 2008.

34. Chaccour C, Hammann F, Ramón-García S, Rabinovich NR. Ivermectin and COVID-19: keeping rigor in times of urgency. Am J Trop Med Hyg. 2020;102(6):1156-7. https://doi.org/10.4269/ ajtmh.20-0271.

35. Schmith VD, Zhou J, Lohmer LR. The approved dose of ivermectin alone is not the ideal dose for the treatment of COVID. Clin Pharmacol. 2020. https://doi.org/10.1002/cpt.1889.

36. Momekov G, Momekova D. Ivermectin as a potential COVID19 treatment from the pharmacokinetic point of view: antiviral levels are not likely attainable with known dosing regimens. Biotechnol Biotechnol Equip. 2020;34(1):469-74. https://doi. org/10.1080/13102818.2020.1775118.

37. Lifschitz A, et al. Comparative distribution of ivermectin and doramectin to parasite location tissues in cattle. Vet Parasitol. 2000;87(4):327-38. https://doi.org/10.1016/s0304 -4017(99)00175-2.

38. Jermain B, Hanafin PO, Cao Y, Lifschitz A, Lanusse C, Rao GG. Development of a minimal physiologically-based pharmacokinetic model to simulate lung exposure in humans following oral 
administration of ivermectin for COVID-19 drug repurposing. J Pharm Sci. 2020. https://doi.org/10.1016/j.xphs.2020.08.024.

39. Yang SNY, Atkinson SC, Wang C, Lee A, Bogoyevitch MA, Borg NA, Jans DA. The broad spectrum antiviral ivermectin targets the host nuclear transport importin $\alpha / \beta 1$ heterodimer. Antiviral Res. 2020;177:104760. https://doi.org/10.1016/j.antiviral.2020.10476 0 .

40. Lundberg L, et al. Nuclear import and export inhibitors alter capsid protein distribution in mammalian cells and reduce venezuelan equine encephalitis virus replication. Antiviral Res. 2013;100(3):662-72.
41. Formiga FR, Leblanc R, de Souza Rebouças J, Farias LP, de Oliveira RN, Pena L. Ivermectin: An award-winning drug with antiviral expectations against COVID-19. J Control Release Off J Control Release Soc. 2020. https://doi.org/10.1016/j.jconr el.2020.10.009.

Publisher's Note Springer Nature remains neutral with regard to jurisdictional claims in published maps and institutional affiliations. 